\title{
PENGARUH PRESTASI PRAKTIK KERJA INDUSTRI DAN HASIL BELAJAR KEWIRAUSAHAAN TERHADAP MINAT BERWIRAUSAHAAN SISWA KELAS XII AKUNTANSI SMK NEGERI 25 JAKARTA
}

\author{
DESTA AMBARSARI \\ Fakultas Ekonomi, Universitas Negeri Jakarta \\ destaambarsari@gmail.com

\section{ATI SUMIATI} \\ Fakultas Ekonomi, Universitas Negeri Jakarta \\ atisumiati@gmail.com
}

\begin{abstract}
This research purpose is to find out the influence of industrial practice and entrepreneurship learning achievement to entrepreneurship interest, XII Accounting Class in SMK Negeri 25 Jakarta. This type of research is survey, with quantitative approach. Data recording, interview and questionnaire are research technique. Sampling technique used proportional random sampling. Total population in this study were 77 students with a sample of 64 students of XII accounting class in SMK Negeri 25 Jakarta. The results showed that: there is a significant positive influence of industrial practice and entrepreneurship learning achievement to entrepreneurship interest, XII Accounting Class in SMK Negeri 25 Jakarta. Thus if industrial practice and entrepreneurship learning achievement increases, the entrepreneurship interest will also increase.
\end{abstract}

Keywords: industrial practice, entrepreneurship learning achievement, entrepreneurship interest. 


\section{PENDAHULUAN}

Seiring dengan bertambah banyaknya jumlah penduduk di Indonesia maka bertambah pula permasalahan yang harus dihadapi, salah satunya adalah menyempitnya lapangan pekerjaan. Akibatnya jumlah pengangguran di Indonesia semakin meningkat. Selain ketersediaan lapangan pekerjaan, kesiapan memasuki dunia kerja juga menjadi penyebab timbulnya pengangguran. Untuk mengatasi terjadinya pengangguran salah satunya menciptakan lapangan pekerjaan sendiri dengan menjadi seorang wirausaha. Wirausaha merupakan salah satu pendukung yang menentukan maju mundurnya perekonomian suatu Negara, karena wirausaha mempunyai kebebasan untuk berkarya dan mandiri.
Di Negara maju wirausahawan menjadi unsur penting dalam menggerakan roda ekonomi. Finance \& Strategy Director and Chief Financial Officer PT Bank Mandiri, Pahala N. Mansury mengungkapkan mayoritas Negara maju memiliki presentase wirausaha yang ideal yaitu minimal $2 \%$ dari jumlah penduduknya. Namun minat berwirausaha di Indonesia masih minim. Hingga bulan Januari 2014 jumlah wirausaha yang ada di Indonesia hanya mencapai $1,5 \%$ (Murdaningsih, 2014).

Dalam suatu kasus, Menteri Koordinator Bidang Kesejahteraan Rakyat, HR. Agung Laksono mengatakan salah satu faktor yang menyebabkan rendahnya tingkat persentase pelaku wirausaha di tanah air, ialah masih kecilnya minat para lulusan lembaga pendidikan, baik sekolah maupun jenjang akademi dan perguruan tinggi. Rendahnya minat tersebut karena lulusan lembaga 
pendidikan cenderung lebih ingin menjadi karyawan. Hal ini dibuktikan dengan presentase lulusan SMA yang ingin bekerja sebesar $61,88 \%$ sedangkan sarjana yang ingin bekerja lebih tinggi lagi presentasenya yaitu mencapai angka 83,20\%. (Mayarakat, 2010)

Rendahnya minat berwirausaha pada siswa karena adanya kesenjangan antara dunia pendidikan dengan dunia kerja. Oleh sebab itu lembaga pendidikan dituntut untuk membentuk entrepreneur agar tidak bergantung pada minimnya ketersediaan lapangan pekerjaan. Sekolah Menengah Kejuruan (SMK) diharapkan dapat mengambil peran tersebut sebagai lembaga pendidikan.
Direktur
Pembinaan
SMK

Kemendikbud, Anang Tjahyono menyatakan guru seharusnya merangsang jiwa wirausaha kepada siswa sejak masuk kelas 10 SMK dengan cara misalnnya mengajak siswa menciptakan ide wirausaha, mendesain ide tersebut dan menghitung biaya yang dibutuhkan. Karena menurutnya selama ini SMK hanya untuk mengisi ketersediaan tenaga kerja bukan pembentukan entrepreneur. (Pitakasari, 2015)

Pendidikan kewirausahaan yang diwajibkan untuk SMA/SMK/MA diharapkan dapat menumbuhkan semangat kewirausahaan sejak dini karena menurut Anthonius Tanan, Presiden Universitas Ciputra Entrepreneurship apabila pendidikan kewirausahaan diajarkan secara tepat akan berdampak pada terbentunya kemandirian. Ia menambahkan jika pendidikan kewirausahaan dikaitkan dengan tujuan pembangunan nasional akan melahirkan pelaku bisnis yang dapat menciptakan lapangan kerja (Hariawan, 2013).

Jika mengacu pada pendidikan kewirausahaan yang dikembangkan Komisi Eropa, tujuan pendidikan kewirausahaan ini untuk membantu siswa memiliki sikap, pengetahuan, dan keterampilan bertindak secara dunia kewiraushaan. Melalui pendidikan kewirausahaan, siswa dibantu untuk memiliki sikap menyadari potensi dirinya dan percaya diri. Selain itu, siswa berinisiatif, berani mengambil risiko, berpikir kritis, kreatif, dan mampu memecahkan masalah. Akan tetapi pendidikan kewirausahaan yang dimiliki guru-guru Indonesia belum mencapai tahap yang baik.

Boyke R Purnomo Dosen FEB UGM mengatakan minat berwirausaha yang terbatas dipengaruhi banyak hal. Mulai dari kurikulum yang tidak mendukung, kesulitan mendesain rancangan perkuliahan hingga instrumen pembelajaran yang tidak sesuai dengan tujuan pembelajaran. Maka dari itu perlunya pembelajaran kewirausahaan, dimulai dari menumbuhkan kewirausahaan, menanamkan nilai-nilai kewirausahaan serta mengajarkan kewirausahaan yang tidak lepas dari aspek kognitif, pembelajaran inovatif, psikomotor dan afektif. (unesa.ac.id, 22 Februari 2015)

Minat berwirausaha tidak hanya timbul dari pendidikan kewirausahaan, tetapi dari pengalaman untuk terjun secara langsung menjadi seorang wirausaha. Pelaksanaan praktik kerja industri (prakerin) yang diberlakukan di SMK diharapkan dapat meningkatkan minat berwirausaha pada siswa. Karena prakerin akan menambah wawasan siswa mengenai dunia usaha dan dunia industri sehingga siswa memiliki gambaran setelah lulus untuk mencari pekerjaan atau membuat lapangan pekerjaan dengan berwirausaha.

Menrut Jondi, pelaksanaan prakerin yang dilakukan di Dunia Usaha/Dunia Industri tidak selamanya sesuai dengan jurusan yang dikuasai siswa. Teguh Hariawan menambahkan banyak kegiatan prakerin yang dipaksakan, tidak peduli apakah tempat prakerin sesuai dengan jurusan bidang keahlian yang selama ini diikuti oleh siswa. Ia mendapati siswa jurusan multimedia 
melaksanakan prakerin di percetakan hanya mendapat tugas menggunting, melipat undangan, dan melaminating. Ini sangat jauh dari disiplin ilmu atau keahlian yang digelutinya. (Jondi, 2013)

Prestasi praktik kerja industri yang ditanamkan dan hasil belajar kewirausahaan yang baik akan sangat membantu penumbuhan minat berwirausaha siswa.

Selain itu, berdasarkan wawancara yang telah dilakukan kepada guru BP/BK SMKN 25 Jakarta, praktik kerja industri dan hasil belajar kewirausahaan siswa dinilai sebagai salah satu faktor yang mempengaruhi minat berwirausaha siswa. Beliau menjelaskan bahwa apabila seorang siswa dapat mengaplikasikan apa yang ia dapat selama melakukan praktik kerja industry, tentunya akan membantu siswa itu sendiri dalam meningkatkan minatnya terhadap bidang kewirausahaan. Sedangkan, apabila siswa mampu mencapai hasil belajar kewirausahaan yang maksimal, maka siswa akan menggabungkan pengetahuan yang ia dapat selama praktik kerja dan teori yang ia terima pada mata pelajaran kewirausahaan dengan cara memulai usaha di kehidupan nyata. Hal seperti itu merupakan contoh kecil yang juga merupakan salah satu faktor dalam meningkatkan minat berwirausaha siswa.

Oleh karena itu, berdasarkan pemaparan yang telah dikemukakan di atas, penelitian dengan judul, Pengaruh Prestasi Praktik Kerja Industri dan Hasil Belajar Kewirausahaan terhadap Minat Berwirausaha Siswa, menjadi hal yang menarik untuk diteliti secara lebih mendalam.

\section{Perumusan Masalah}

Berdasarkan pemaparan yang telah dilakukan di atas, maka perumusan masalah dalam penelitian adalah: "Adakah pengaruh prestasi praktik kerja industri dan hasil belajar kewirausahaan terhadap minat berwirausaha pada siswa?"

\section{KAJIAN PUSTAKA}

Prestasi Praktik Kerja Industri

Dimyati dan Mudjiono (Mudjono, 2006)

mengatakan bahwa prestasi adalah hasil yang dicapai dalam bentuk angka-angka atau skor setelah diberikan tes hasil belajar pada setiap akhir pembelajaran.

Selanjutnya menurut Agus Suprijono (Suprijono, 2009) prestasi adalah pola-pola perbuatan, nilai-nilai, pengertian-pengertian, sikap-sikap, apresiasi, dan keterampilan.

Djamarah

(Djamarah, 1994)mengungkapkan prestasi adalah hasil suatu kegiatan yang telah dikerjakan, diciptakan baik secara individu maupun kelompok.

Made Wena (Wena, 1996) mengungkapkan prakerin adalah kegiatan yang dilakukan oleh peserta didik berupa praktik langsung pada dunia kerja yang nyata.

Oemar Hamalik (Hamalik, 1990) mengemukakan bahwa praktik industri atau dibeberapa sekolah disebut dengan On The Job Training (OJT) merupakan modal pelatihan yang diselenggarakan di lapangan, bertujuan untuk memberikan kecakapan yang diperlukan dalam pekerjaan tertentu sesuai dengan tuntutan kemampuan bagi pekerjaan.

Dalam kurikulum SMK (Dikmenjur, 2008) disebutkan bahwa prakerin adalah bagian dari program pembelajaran yang harus dilaksanakan oleh setiap peserta didik di dunia kerja, sebagai wujud nyata dari pelaksanaan sistim pendidikan di SMK yaitu Pendidikan Sistim Ganda (PSG).

Berdasarkan beberapa pengertian yang telah dijelaskan di atas, maka prestasi praktik kerja industri dapat disimpulkan sebagai pencapaian hasil yang diarahkan terhadap tercapainya suatu nilai dari pendidikan yang mengintegrasikan kegiatan pendidikan di 
sekolah dengan kegiatan pendidikan di dunia industri.

Menurut Suyanto (1996:77) ada empat tujuan dari sistem ganda (magang), yaitu:

1. Membuka setting dunia kerja dan masyarakat sebagai lingkungan belajar bagi siswa.

2. Menghubungkan pengalaman kerja dengan pengajaran akademik.

3. Memberi peran para siswa secara konstruktif sebagai pekerja disertai tanggung jawabnya sebagai peserta didik.

4. Menanamkan hubungan yang erat antara peserta didik dan pekerja dewasa yang bertindak sebagai mentor.

Sedangkan Soewarni (1996:78) dan
$\begin{aligned} & \text { Sulaiman menyebutkan tujuan } \\ & \text { penyelenggaraan sistem ganda adalah: }\end{aligned}$

1. Menghasilkan tenaga kerja yang memiliki keahlian professional dengan tingkat pengetahuan, keterampilan, dan etos kerja yang sesuai dengan tuntutan lapangan kerja.

2. Memperoleh link and match antara sekolah dan dunia kerja

3. Meningkatkan efisiensi proses pendidikan dan pelatihan tenaga kerja yang berkualitas dan professional

4. Memberi pengakuan dan penghargaan terhadap pengalaman kerja sebagai bagian dari proses pendidikan

Menurut Oemar Hamalik

tujuan program pendidikan sistem ganda yaitu:

1. Menyajikan pengalaman on the job di lingkungan industri.Pengalaman yang diperoleh adalah yang bersifat praktis dan fungsional yang mendukung penguasaan teori di lembaga pendidikan.

2. Memperoleh pemahaman secara luas, menyeluruh, dan mendalam tentang fungsi, peranan, dan kegiatan industri.
Dalam program ini siswa/peserta didik dapat memperoleh pemahaman melalui belajar langsung di lingkungan industri tersebut.

3. Mengembangkan kompetensi dalam bidang teknik industri. Dalam arti luas, kompetensi itu mencakup unsur-unsur pengetahuan, sikap, dan keterampilan bidang teknik industri, sedangkan dalam arti sempit memupuk keterampilan teknik industri melalui kegiatan langsung di lingkungan suatu industri.

4. Mengembangkan pengalaman hubungan antara manusia yakni bagaimana bergaul dan bermasyarakat di lingkungan ketenagaan industri.

5. Memperluas pengalaman guru-guru pendidikan industri. Pengalaman ini mereka peroleh selama berpartisipasi dalam mengadakan pertemuan konsultasim keterlibatan dalam bimbingan terhadap siswa, dan pengamatan secara langsung. Pengalaman ini memberikan dampak yang turut meningkatkan kualifikasi professional guru-guru bersangkutan.

6. Selama berlangsungnya praktik kerja ini, perlu diadakan semacam bimbingan atau supervise klimis yang tujuannya untuk perbaikan kemampuan para peserta. Banyak masalah yang perlu dipecahkan bersama antara guru-guru, para siswa, pembimbing ditingkat perusahaan. Melalui kebersamaan dan keterpaduan semua pihak yang terkait, diharapkan program praktik kerja ini berhasil optimal.

Berdasarkan tujuan-tujuan sistem ganda seperti yang diungkapkan diatas dapat disimpulkan bahwa tujuan utama dari program praktik kerja industri adalah mengoptimalkan hasil pembelajaran pada pendidikan kejuruan. Dengan kata lain menghasilkan lulusan lembaga pendidikan kejuruan yang memiliki pengetahuan, keterampilan dan etos kerja yang sesuai 
dengan tuntutan dunia kerja serta memberikan pengalaman siswa dan wawasan tentang dunia kerja secara nyata.

\section{Hasil Belajar Kewirausahaan}

Purwanto (Purwanto, 2011)menjelaskan bahwa hasil belajar merupakan pencapaian tujuan pendidikan pada siswa yang mengikuti proses belajar mengajar.

Sedangkan Nana Sudjana (Sudjana, 2009) mengatakan bahwa hasil belajar siswa pada hakikatnya adalah perubahan tingkah laku yang dalam pengertian luas mencakup bidang kognitif, afektif, dan psikomotorik.

Ini diperkuat dengan pendapat dari Anas Sudjiono (Sudjiono, 2005) yang menyatakan bahwa "Prestasi atau pencapaian peserta didik yang dilambangkan dengan nilai hasil belajar pada dasarnya mencerminkan sejauh mana tingkat keberhasilan yang telah dicapai oleh peserta didik dalam pencapaian tujuan pendidikan yang telah ditentukan bagi masingmasing pelajaran atau bidang studi."

Berdasarkan berbagai uraian tersebut dapat disimpulkan bahwa hasil belajar adalah hasil yang diperoleh dari proses belajar yang mengakibatkan adanya perubahan dalam diri siswa yang dinyatakan dalam simbol angka atau huruf. Sedangkan mata pelajaran kewirausahaan adalah salah satu mata diklat yang lebih menekankan pada kegiatan penciptaan suatu usaha tertentu. Sehingga hasil belajar kewirausahaan adalah pencapaian yang diperoleh siswa pada mata pelajaran kewirausahaan terkait dengan penciptaan suatu usaha yang dinyatakan dengan angka atau huruf.

Menurut Slameto faktor- faktor yang mempengaruhi hasil belajar yaitu :

\section{Faktor internal}

Faktor internal adalah faktor yang ada dalam individu yang sedang belajar seperti:
a. Faktor Jasmaniah, meliputi: Faktor kesehatan dan cacat tubuh.
b. Faktor Psikologi, meliputi: Intelegensi, perhatian, minat, bakat, motivasi, kematangan, dan kesiapan.
c. Faktor Kelelahan

2. Faktor Eksternal
a. Keadaan keluarga
b. Keadaan sekolah
c. Keadaaan masyarakat

Selanjutnya Suryabrata (2008:233) mengklasifikasikan faktor-faktor yang mempengaruhi hasil belajar adalah:

a) Faktor yang berasal dari dalam diri (internal), yaitu:

Faktor fisiologis seperti jasmani, keadaan fungsi fiologis. Faktor psikologis seperti perhatian, pengamatan, tanggapan, fantasi, ingatan, berfikir dan motif.

b) Faktor yang berasal dari luar diri (eksternal), terdiri dari : Faktor non sosial seperti udara, suhu, cuaca, waktu, tempat, alat - alat yang dipakai untuk belajar. Dan faktor sosial seperti manusia.

Lalu, menurut Purwanto (Purwanto, 2011) hasil belajar dipengaruhi oleh faktorfaktor sebagai berikut:

a) Faktor yang ada pada diri organisme itu sendiri yang disebut faktor individual. Yang termasuk ke dalam faktor individual antar lain: faktor kematangan/pertumbuan, kecerdasan, latihan, motivasi, dan faktor pribadi.

b) Faktor yang ada di luar individu yang disebut faktor sosial. Yang termasuk ke dalam faktor sosial antara lain faktor keluarga/keadaan rumah tangga, guru dan cara mengajarnya, alat-alat yang dipergunakan dalam belajar mengajar, lingkungan dan kesempatan yang tersedia, dan motivasi sosial.

\section{METODE PENELITIAN}

Tujuan penelitian ini adalah untuk mendapatkan pengetahuan berdasarkan fakta yang tepat, shahih, dan dapat dipercaya tentang pengaruh prestasi praktik kerja industri 
dan hasil belajar kewirausahaan terhadap minat berwirausaha siswa XII akuntansi SMK Negeri 25 Jakarta.

Metode yang digunakan dalam penelitian ini adalah metode survey dengan pendekatan korelasional.

Populasi dalam penelitian ini adalah seluruh siswa di SMKN 25 Jakarta. Adapun populasi terjangkaunya yaitu siswa kelas XII Jurusan Akuntansi yang dengan jumlah siswa sebanyak 77 siswa yang terbagi dalam 2 kelas. Kemudian berdasarkan tabel Isaac dan Michael dengan taraf kesalahan 5\%, maka jumlah sampel sebanyak 64 siswa.

Sebelum dilakukan pengujian hipotesis, terlebih dahulu dilakukan pengujian persyaratan analisis, meliputi Uji Normalitas dan Uji Linearitas.

Teknik yang digunakan untuk melakukan pengujian normalitas data adalah Uji Kolmogorov-Smirnov. Data yang terkumpul kemudian dianalisis dengan regresi dan korelasi.

\section{HASIL DAN PEMBAHASAN}

Berikut adalah distribusi data hasil penelitian.

\section{Tabel 1.Rangkuman Deskripsi Data}

\begin{tabular}{|l|c|c|c|}
\hline $\begin{array}{c}\text { Nendai } \\
\text { Sentral }\end{array}$ & $\begin{array}{c}\text { Prestasi } \\
\text { Praktik } \\
\text { Kerja } \\
\text { Industri } \\
(\mathrm{X} 1)\end{array}$ & $\begin{array}{c}\text { Hasil Belajar } \\
\text { Kewirausaha } \\
\text { an (X2) }\end{array}$ & $\begin{array}{c}\text { Minat } \\
\text { Berwira } \\
\text { usaha } \\
\text { Siswa } \\
\text { (Y) }\end{array}$ \\
\hline $\mathrm{n}$ & 64 & 64 & 64 \\
\hline Mean & 85,05 & 89,47 & 86,91 \\
\hline $\begin{array}{l}\text { Std. } \\
\text { Deviasi }\end{array}$ & 4,053 & 5,480 & 7,615 \\
\hline Varians & 16,426 & 30,031 & 57,991 \\
\hline
\end{tabular}

Uji Persyaratan Analisis Uji Normalitas
Pengujian normalitas yang digunakan adalah Uji Kolmogorov-Smirnov. Hasil Uji Normalitas terdapat pada tabel 2 berikut:

\section{Tabel 2. Hasil Uji Normalitas}

Berdasarkan hasil perhitungan uji normalitas menyatakan bahwa data dari ketiga variabel berdistribusi normal. Hal ini

One-Sample Kolmogorov-Smirnov Test

\begin{tabular}{|c|c|c|c|c|}
\hline & & $\begin{array}{l}\text { Prestasi_- } \\
\text { Prakerin }\end{array}$ & $\begin{array}{c}\text { HasilBela } \\
\text { jar_Kewir } \\
\text { ausahaan }\end{array}$ & $\begin{array}{c}\text { Minat_Be } \\
\text { rwirausah } \\
\text { a }\end{array}$ \\
\hline \multicolumn{2}{|l|}{$\mathrm{N}$} & 64 & 64 & 64 \\
\hline \multirow{2}{*}{$\begin{array}{l}\text { Normal } \\
\text { Parameters }\end{array}$} & Mean & 85.05 & 89.47 & 86.91 \\
\hline & $\begin{array}{l}\text { Std. } \\
\text { Deviation }\end{array}$ & 4.053 & 5.480 & 7.615 \\
\hline \multirow{3}{*}{$\begin{array}{l}\text { Most Extreme } \\
\text { Differences }\end{array}$} & Absolute & .169 & .148 & .094 \\
\hline & Positive & .096 & .094 & .094 \\
\hline & Negative & -.169 & -.148 & -.052 \\
\hline \multirow{2}{*}{\multicolumn{2}{|c|}{ Kolmogorov-Smirnov Z }} & $\begin{array}{r}1.356 \\
051\end{array}$ & $\begin{array}{r}1.184 \\
121\end{array}$ & $\begin{array}{r}.748 \\
630\end{array}$ \\
\hline & & .051 & .121 & .630 \\
\hline
\end{tabular}

dibuktikan dengan tingkat signifikansi kolmogorov-smirnov untuk variabel minat berwirausaha sebesar 0.630 , prestasi prakerin sebesar 0,051, dan hasil belajar 0,121. Tingkat signifikansi ketiga variabel tersebut $>0,05$.

\section{Uji Linearitas}

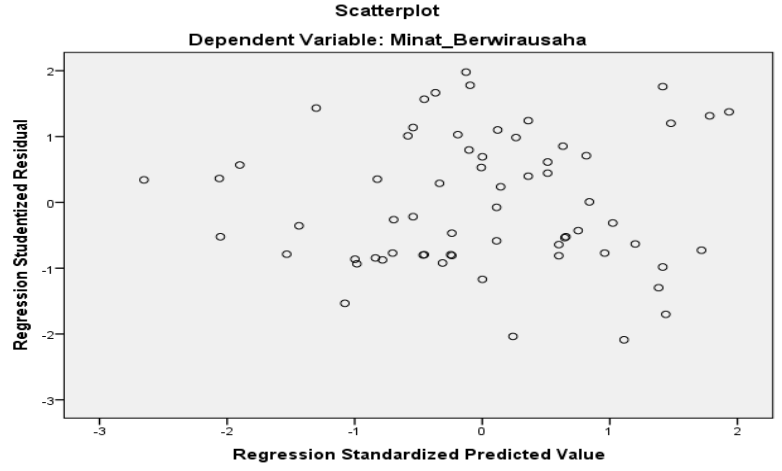

Berdasarkan gambar diatas terlihat bahwa titik-titik peneyebaran terletak antara -2 dan +2 , hal ini menyatakan bahwa asumsi linieritas antara prestasi prakerin, hasil belajar kewirausahaan, dan minat berwirausaha terpenuhi.

\section{Pengujian Hipotesis}


Hasil analisis data menginformasikan bahwa persamaan regresi pasangan variabel ini adalah $Y=-27,186+0,733 X_{1}+0,578 X_{2}$. Hasil pengujian signifikansi pada persamaan regresi Tabel 3 ANOVA ${ }^{a}$

\begin{tabular}{|c|c|c|c|c|c|c|}
\hline \multicolumn{2}{|c|}{ Model } & $\begin{array}{c}\text { Sum of } \\
\text { Squares }\end{array}$ & $\mathrm{df}$ & $\begin{array}{l}\text { Mean } \\
\text { Square }\end{array}$ & $\mathrm{F}$ & Sig. \\
\hline \multirow{3}{*}{1} & $\begin{array}{l}\text { Regress } \\
\text { ion }\end{array}$ & 1468.481 & 2 & 734.240 & $\begin{array}{r}20.49 \\
9\end{array}$ & $.000^{\mathrm{b}}$ \\
\hline & $\begin{array}{l}\text { Residu } \\
\text { al }\end{array}$ & 2184.957 & 61 & 35.819 & & \\
\hline & Total & 3653.438 & 63 & & & \\
\hline
\end{tabular}

a. Dependent Variable: Minat_Berwirausaha

b. Predictors: (Constant), HasilBelajar_Kewirausahaan, Prestasi_Prakerllabel 5 Model Summary ${ }^{b}$

\begin{tabular}{|c|c|c|c|c|}
\hline $\begin{array}{l}\text { Mod } \\
\text { el }\end{array}$ & $\mathrm{R}$ & $\begin{array}{c}\mathrm{R} \\
\text { Square }\end{array}$ & $\begin{array}{l}\text { Adjusted R } \\
\text { Square }\end{array}$ & $\begin{array}{l}\text { Std. Error of } \\
\text { the Estimate }\end{array}$ \\
\hline 1 & $.634^{\mathrm{a}}$ & .402 & .382 & 5.985 \\
\hline $\begin{array}{l}\text { a. Pr } \\
\text { Prest } \\
\text { b. De } \\
\text { Sun }\end{array}$ & $\begin{array}{l}\text { rs: }(C \\
\text { rakeri } \\
\text { ent } \mathrm{V} \\
: \mathrm{Da}\end{array}$ & $\begin{array}{l}\text { stant), H } \\
\text { ble: Mi } \\
\text { diolah }\end{array}$ & $\begin{array}{l}\text { ilBelajar_Ke } \\
\text { t_Berwirausa } \\
\text { ahun } 201\end{array}$ & ha \\
\hline
\end{tabular}

disajikan pada tabel 3 diatas.

Berdasarkan tabel di atas, maka dapat disimpulkan bahwa prestasi prakerin dan hasil belajar kewirausahaan berpengaruh secara serentak terhadap minat berwirausaha.

Selanjutnya, Uji $\mathrm{t}$ untuk mengetahui pengaruh variabel bebas sacara parsial terhadap variabel terikat, apakah pengaruhnya signifikan atau tidak. Hasil pengujian disajikan pada tabel 4.

Tabel 4. Coefficients ${ }^{\mathrm{a}}$

\begin{tabular}{|c|c|c|c|c|c|}
\hline \multirow[t]{2}{*}{ Model } & \multicolumn{2}{|c|}{$\begin{array}{l}\text { Unstandardized } \\
\text { Coefficients }\end{array}$} & \multirow{2}{*}{$\begin{array}{c}\text { Standardized } \\
\text { Coefficients } \\
\text { Beta }\end{array}$} & \multirow[t]{2}{*}{$\mathrm{t}$} & \multirow[t]{2}{*}{ Sig. } \\
\hline & B & Std. Error & & & \\
\hline (Constant) & 27.186 & 18.136 & & -1.499 & .139 \\
\hline $\begin{array}{l}\text { Prestasi_Pr } \\
\text { akerin }\end{array}$ & .733 & .191 & .390 & 3.830 & .000 \\
\hline $\begin{array}{l}\text { HasilBelaja } \\
\text { r_Kewiraus } \\
\text { ahaan }\end{array}$ & .578 & .142 & .416 & 4.085 & .000 \\
\hline
\end{tabular}

a. Dependent Variable: Minat_Berwirausaha

Berdasarkan hasil pengujian pada tabel 4 , diperoleh $t$ hitung sebesar 3,830 (untuk variabel X1) dan 4,085 (untuk variabel X2) yang lebih besar dari nilai t tabel yakni 2,000, nilai $\mathrm{t}$ tabel dapat dicari pada tabel statistik pada signifikansi $0,05 / 2=0,025$ (uji dua sisi). Jadi kesimpulannya secara parsial ada hubungan yang signifikan antara prestasi prakerin dengan minat berwirausaha dan secara parsial ada yang signifikan antara hasil belajar kewirausahaan dengan minat berwirausaha.

Selanjutnya, untuk mengetahui derajat hubungan antara variabel disiplin belajar (X1), persepsi siswa tentang keterampilan mengajar guru (X2), dan hasil belajar (Y) yang disajikan pada tabel 5 Summary berikut.

Berdasarkan tabel 5 Summary, dapat diketahui nilai $\mathrm{R}$ sebesar 0,634 berarti nilai $\mathrm{R}$ termasuk kategori $(0,60-0,799)$, maka keeratan hubungan antara prestasi prakerin (X1), hasil belajar kewirausahaan (X2) dengan minat berwirausaha (Y) tergolong kuat.

Koefisien determinasi yang dilihat dari kolom R Square sebesar 0,402 menunjukkan bahwa sebesar $40,2 \%$ variabel yang terdapat pada minat berwirausaha ditentukan oleh variabel prestasi prakerin dan hasil belajar kewirausahaan dengan persamaan regresi $\hat{\mathrm{Y}}=$ $-27,186+0,733 X_{1}+0,5 / 8 X_{2}$.

\section{KESIMPULAN, IMPLIKASI, DAN SARAN \\ Kesimpulan \\ Berdasarkan pengolahan data,} pengetahuan deskripsi, analisis dan pembahasan data yang telah dilakukan dan diuraikan pada bab-bab sebelumnya maka disimpulkan bahwa terdapat pengaruh secara serentak antara prestasi prakerin dan hasil belajar kewirausahaan terhadap minat berwirausaha sebesar empat puluh koma dua persen.

\section{Implikasi}

Setelah dilakukan penelitian mengenai pengaruh prestasi praktik kerja industri dan hasil belajar kewirausahaan dengan minat berwirausaha siswa kelas XII jurusan 
akuntansi SMKN 25 Jakarta tahun 2015, diketahui bahwa implikasinya adalah sebagai berikut:

1. Berdasarkan hasil penelitian diketahui bahwa skor minat berwirausaha siswa tertinggi terdapat pada indikator berorientasi ke masa depan yang artinya bahwa minat berwirausaha dapat terlaksana dengan adanya sikap siswa yang lebih memperhatikan kemungkinankemungkinan yang akan terjadi di masa depan. Skor kesiapan belajar terendah terdapat pada indikator berani menanggung risiko dan memiliki kemampuan memimpin.

Pada indikator berani menanggung risiko menunjukkan bahwa sebagian siswa akuntansi masih belum bisa mengendalikan risiko yang akan terjadi dari sebuah usaha. Hal ini bisa disebabkan oleh kurang bervariasinya metode pembelajaran guru di sekolah, misalnya pada pembelajaran kewirausahaan hanya diberikan teori saja sedangkan praktiknya tidak diikutsertakan sehingga menyebabkan siswa tidak tahu bagaimana caranya berwirausaha dan bagaimana mengendalikan risiko yang mungkin terjadi.

Selain itu, indikator memiliki kemampuan memimpin merupakan skor indikator kedua terendah yang artinya bahwa indikator memiliki kemampuan memimpin tersebut mengindikasikan bahwa siswa memiliki kemampuan memimpin sebuah usaha yang rendah. Hal ini terjadi karena siswa belum memiliki inisiatif dalam dirinya sehingga kemampuan memimpinnya masih belum terbentuk pada diri siswa tersebut. Jika siswa memiliki kemampuan memimpin yang rendah akan menyebabkan siswa enggan memiliki usaha sendiri atau berwirausaha.

2. Prestasi praktik kerja industri dan hasil belajar kewirausahaan merupakan faktor yang dapat mempengaruhi minat berwirausaha siswa. Namun hubungan antara kedua faktor tersebut hanya sebesar 40,2\%. Hal ini menunjukkan masih banyak faktor-faktor lain yang mempengaruhi minat berwirausaha. Faktor-faktor lain tersebut juga harus dimiliki oleh siswa disamping kedua faktor yang telah dibahas dalam penelitian ini agar dapat menumbuhkan minat berwirausaha sejak dini.

\section{Saran}

Berdasarkan kesimpulan dan implikasi yang dikemukakan di atas, saran-saran yang dapat diberikan peneliti adalah:

1) Siswa harus meningkatkan minat berwirausaha terutama dengan meningkatkan keberaniannya dalam menghadapi risiko dan meningkatkan kemampuannya dalam memimpin. Siswa harus lebih banyak mempraktikan teori kewirausahaan yang diberikan di sekolah ke dalam kehidupan nyata. Siswa harus senantiasa menyadari akan kebutuhan untuk mengembangkan potensi diri.

2) Sekolah harus ditingkatkan lagi perannya dalam menumbuhkan minat berwirausaha siswa. Dan juga sebaiknya sekolah tidak terlalu mengarahkan siswanya ketika lulus untuk menjadi pencari kerja. Namun, membuka lapangan pekerjaan dengan menjadi wirausaha.

3) Penelitian selanjutnya agar meningkatkan kualitas penelitian lebih lanjut khususnya yang berkaitan dengan prestasi prakerin dan hasil belajar kewirausahaan dengan minat berwirausaha.

4) Guru harus lebih bervariasi dalam memberikan metode belajar pada siswa caranya dengan mengikutsertakan guru kedalam pelatihan-pelatihan agar wawasan mengenai media dan metode 
pembelajaran yang dimiliki guru terus berkembang.

\section{DAFTAR PUSTAKA}

Djamarah. (1994). Prestasi Belajar dan Kompetensi Guru. Surabaya: Usaha Nasional.

Hamalik, O. (1990). Pendidikan Tenaga Kerja Nasional. Bandung : PT Bumi Aksara.

Hariawan, T. (2013). Hariawan, Teguh. Jakarta:

http://edukasi.kompasiana.com/2 013/05/19/kasihan.

Jondi. (2013). praktek kerja lapangan pkl siswa smk. http://edukasi.kompasiana.com/2 013/02/07/praktek-kerjalapangan-pkl-siswa-smk531641.html.

Mayarakat, K. K. (2010). Menkokesra: Minat Berwiraswasta Orang Indonesia Masih Rendah. Jakarta:

http://2010.kemenkopmk.go.id/c ontent/menko-kesra-minatberwiraswasta-orangindonesiamasih-rendah.

Mudjono, D. d. (2006). Belajar dan Pembelajaran. Jakarta: Depdikbud.

Murdaningsih, D. (2014). Wirausaha Indonesia baru 15 Persen Jauh Dibanding Singapura. Indonesia: http://www.republika.co.id/berita /ekonomi/makro/13/01/14mgmd 77-wirausaha-indonesia-baru-15- persen-jauh-dibandingsiangapura.

Pitakasari, A. R. (2015). Agar Tidak Menjadi Pengangguran Intelek. Jakarta:

http://nasional.sindonews.com/ read/716228/agar-tak-jadipengangguran-intelek1360487837.

Purwanto, N. (2011). Evaluasi Hasil Belajar. Yogyakarta: Pustaka Pelajar.

Slameto. (2010). Belajar dan Faktor Faktor yang Mempengaruhinya. Jakarta: Rineka Cipta.

Slameto. (2010). Belajar dan Faktor Faktor yang Mempengaruhinya. Jakarta: Rineka Cipta.

Sudjana, N. (2009). Penilaian Hasil Proses Belajar Mengajar. Bandung : PT Remaja Rosdakarya.

Sudjiono, A. (2005). Pengantar Evaluasi Pendidikan. Jakarta: PT Raja Grafindo Persada.

Suprijono, A. (2009). Cooperative Learning Teori dan Aplikasi Paikem. Yogyakarta: Pustaka Belajar.

Wena, M. (1996). Pendidikan Sistem Ganda. Bandung: Tarsito. 